\title{
Soil Erosion and Surface Water Quality Impacts of Natural Gas Development in East Texas, USA
}

\author{
Matthew McBroom ${ }^{1, *}$, Todd Thomas ${ }^{2}$ and Yanli Zhang ${ }^{1}$ \\ 1 Arthur Temple College of Forestry and Agriculture, Stephen F. Austin State University, \\ Nacogdoches, TX 75962, USA; E-Mail: zhangy2@sfasu.edu \\ 2 Texas A\&M Forest Service, Lufkin, TX 75901, USA; E-Mail: tthomas@tfs.tamu.edu \\ * Author to whom correspondence should be addressed; E-Mail: mcbroommatth@sfasu.edu; \\ Tel.: +1-936-468-2469.
}

Received: 27 September 2012; in revised form: 10 November 2012 / Accepted: 12 November 2012 / Published: 20 November 2012

\begin{abstract}
Due to greater demands for hydrocarbons and improvements in drilling technology, development of oil and natural gas in some regions of the United States has increased dramatically. A 1.4 ha natural gas well pad was constructed in an intermittent stream channel at the Alto Experimental Watersheds in East Texas, USA (F1), while another 1.1 ha well pad was offset about $15 \mathrm{~m}$ from a nearby intermittent stream (F2). V-notch weirs were constructed downstream of these well pads and stream sedimentation and water quality was measured. For the 2009 water year, about $11.76 \mathrm{~cm}$, or almost $222 \%$ more runoff resulted from F1 than F2. Sediment yield was significantly greater at F1, with $13,972 \mathrm{~kg} \mathrm{ha}^{-1} \mathrm{yr}^{-1}$ versus $714 \mathrm{~kg} \mathrm{ha}^{-1} \mathrm{yr}^{-1}$ at $\mathrm{F} 2$ on a per unit area disturbance basis for the 2009 water year. These losses were greater than was observed following forest clearcutting with best management practices (111-224 kg ha ${ }^{-1}$ ). Significantly greater nitrogen and phosphorus losses were measured at F1 than F2. While oil and gas development can degrade surface water quality, appropriate conservation practices like retaining streamside buffers can mitigate these impacts.
\end{abstract}

Keywords: water quality; surface runoff; oil and natural gas development; fracking; sedimentation; erosion; APEX model; best management practices; riparian buffers 


\section{Introduction}

Recent advances in drilling technology have resulted in a dramatic expansion in exploration for and development of oil and natural gas. Historically, single vertical wells were drilled into hydrocarbon traps in permeable rock formations where gas and oil had migrated to. Starting in the 1940s, water, sand, and other additives under high pressure were used to fracture low permeability hydrocarbon source rocks like shales. Due to the high cost of these operations relative to the value of the oil and gas recovered, this practice had only limited applicability. Recent advances in horizontal drilling technology coupled with higher prices for oil and natural gas have resulted in a significant increase in hydraulic fracturing or fracking. In addition, $\mathrm{CO}_{2}$ emissions from natural gas combustion are $30 \%-40 \%$ lower than coal, NOx emissions are $80 \%$ lower for natural gas, and emissions are almost $100 \%$ lower for $\mathrm{SO}_{2}$, particulates, and mercury compared with coal [1]. Therefore, natural gas is seen as an acceptable bridge fuel until more sustainable energy sources become viable. This will likely result in greater development of natural gas resources in the future.

One area of very active drilling in the United States is East Texas, southwestern Arkansas, and western Louisiana. The Haynesville, Cotton Valley, Travis Peak, and other formations underlie this region and have been very productive, with a drilling success rate of over $99 \%$. The Haynesville shale has been the most productive formation and is between 3.1 and $4.3 \mathrm{~km}$ deep and about $91 \mathrm{~m}$ in thickness [2]. It is estimated to contain about 7 trillion $\mathrm{m}^{3}$ of natural gas [3]. Drilling increased by over $300 \%$ in the Haynesville region from 2008 to 2012.

There are numerous concerns associated with oil and gas development and water resources. These include firstly, the large amount of water used in fracking. In the Barnett shale, fracking water use in 2010 was $308 \mathrm{Mm}^{3}$, or about $9 \%$ of the total water used by the city of Dallas, Texas [4]. In addition, concerns exist about the possibility of fracking fluids contaminating aquifers. With regards to surface waters, leaking pipelines, reserve pits, and producer water spills are a significant hazard [5]. Finally, concerns exist about the erosion and sedimentation that can result from natural gas development. Sedimentation is among the greatest contributors to stream impairment in the United States [6].

In the Barnett shale region of north Texas, sediment yields from natural gas sites in Denton County were $54 \mathrm{t} \mathrm{ha}^{-1} \mathrm{yr}^{-1}$, much greater than the $1.1 \mathrm{t} \mathrm{ha}^{-1} \mathrm{yr}^{-1}$ measured from undisturbed rangelands in this region [7]. The United States Environmental Protection Agency (USEPA) regulates small construction sites ( 0.4 ha or greater) for stormwater discharge and sediment movement. In the state of Texas, gas wells are not regulated by the state environmental agency as small construction sites and are not subject to the same regulations. In addition, little regulatory oversight is given to how the placement of well pads may impact surface water resources.

Best management practices (BMPs) to control stormwater discharge and nonpoint pollution for other industries like agriculture and forestry have been widely adopted in the USA. For example, over 95\% of forestry operations in Texas employ these BMPs [8], and these BMPs have been proven to be very effective in reducing sedimentation from clearcutting and site-preparation [9]. Similarly, it is estimated that sedimentation from natural gas well sites could be reduced by as much as $93 \%$ by using BMPs [10].

The purpose of this study was to quantify the stormwater concentrations and losses of sediment, nutrients, and metals from a natural gas well site. Comparisons were made between a gas well site 
constructed in the stream channel and a site offset from the stream channel by $15 \mathrm{~m}$ to determine the extent to which well location may affect sediment loss and water quality. Comparisons were also made between these water quality impacts and impacts from other land uses in the watersheds.

\section{Materials and Methods}

\subsection{Study Area}

The study was conducted at the Alto Experimental Watersheds in the Neches River basin approximately $16 \mathrm{~km}$ west of the town of Alto in Cherokee County, Texas, USA (Figure 1). The study area is in the Gulf Coastal Plain and has a humid subtropical climate. Average summer temperatures are $27.2^{\circ} \mathrm{C}$ and average winter temperatures are $9.5^{\circ} \mathrm{C}$, with a mean annual temperature of $18.7^{\circ} \mathrm{C}$. Annual rainfall in the region is $117 \mathrm{~cm}$. The rain is distributed fairly evenly throughout the year with an average of 89 rain days a year, with April and May receiving the largest amount of rainfall [11].

Figure 1. Location of study watersheds $(\mathrm{F} 1=$ no riparian buffer, $\mathrm{F} 2=15 \mathrm{~m}$ riparian buffer $)$ at the Alto Experimental Watersheds in Cherokee County, Texas, USA.

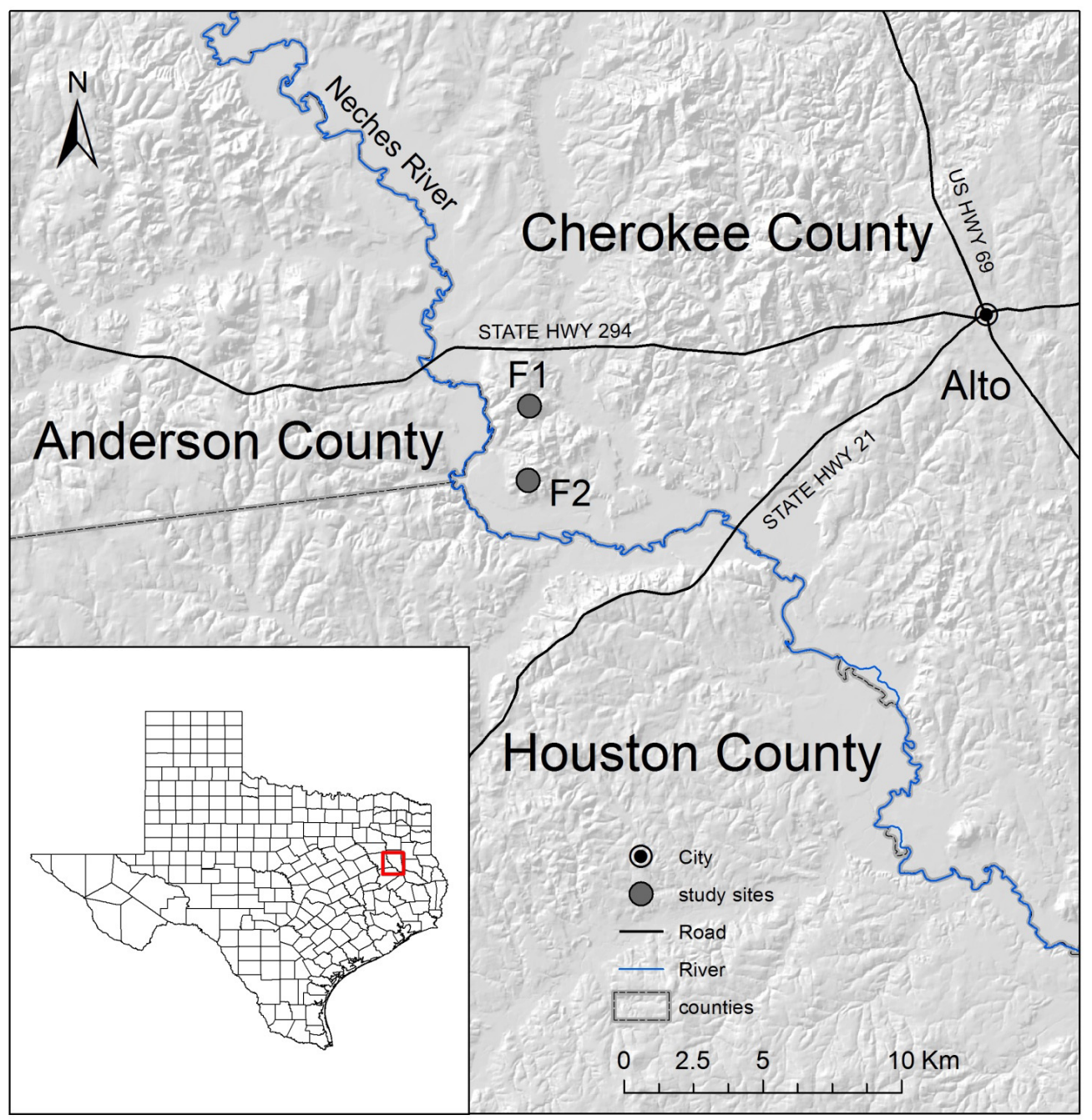

The soils at the Alto Experimental Watersheds formed in Eocene sediments. The dominant surface formations are members of the Claiborne Group and are Sparta Sand and the Cook Mountain 
Formation [12]. These soils developed under mixed loblolly pine (Pinus taeda) and hardwood forests, have low inherent fertility and are most commonly classified as Alfisols and Ultisols. The most prevalent soil found in the watersheds is the Sacul Series (fine, mixed, active, thermic Aquic Hapludults) followed by the Tenaha Series (loamy, siliceous, semiactive, thermic Arenic Hapludults). Both soils are Ultisols with an argillic horizon and less than $35 \%$ base saturation. Teneha soils are well drained and runoff is negligible to medium with increasing slope [13]. Sacul soils are slowly permeable soils that formed in acidic, loamy and clayey marine sediments. They are moderately well drained with medium to very high runoff potential, and have a seasonally high water table that is within 61 to $122 \mathrm{~cm}$ of the soil surface in late winter and spring most years [13].

\subsection{Treatments}

In the spring of 2008, two natural gas wells were drilled. At the first site (F1), the well pad was constructed directly in the channel of an intermittent stream and has a watershed area of 13.7 ha with the pad comprising 1.4 ha (Figure 2a). The stream was rechanneled around the north side of the pad following construction. At the second site (F2), the pad was offset from the creek channel by about 15 meters; this site has a watershed that consists of 4.5 ha with the well pad occupying 1.1 ha (Figure 2b).

In the process of constructing the well pad at F-1, fill material had to be brought in from an undisclosed location. The fill material consisted of 55.5\% sand and $44.5 \%$ clay. Once this fill material had been brought in and the site leveled, iron ore gravel (16-150 $\mathrm{mm}$ diameter) was hauled in and spread over the majority of the pad with the exception of approximately one-quarter of the western end of the pad, which was used for a drilling fluid reserve pit. After drilling was completed, the reserve pit was filled with soil that was $40.2 \%$ sand, $14.1 \%$ silt, and $45.7 \%$ clay. This area was then seeded with ryegrass (Lolium spp.) While some of the seeds germinated, most did not grow or were carried away by surface runoff, resulting in bare soil.

The well pad at F2 required no fill material for pad construction due to the topography of the site. F2 was placed on the southern face of a large hill. Earth-moving equipment was used to modify the hill from a steep slope to a 1.1 hectare terrace suitable for operating large drilling equipment on. This soil was $65.1 \%$ sand, $9.5 \%$ silt, and $25.3 \%$ clay. After the terrace was constructed, iron ore gravel was spread similar to the method employed at F1. The back, southern portion used as a reserve pit for drilling fluids. The soil used to fill in the reserve pit was $21.7 \%$ sand, $32.1 \%$ silt, and $46.2 \%$ clay.

Both sub-watersheds where the gas well sites were constructed were dominated by loblolly pine. The northern portion of the F1 watershed was mixed hardwoods and pine; this area comprised approximately 3.5 hectares. The rest of the F1 watershed was 10-15 year old loblolly pine plantation. Approximately 2 hectares of the F2 watershed was 10-15 year old loblolly pine plantation while the rest was a mixed hardwood and pine stand. The portion of the watershed that was mixed hardwood and pine was composed of fairly large $(\approx 50-100 \mathrm{~cm})$ timber. These larger diameter trees consisted primarily of white and red oaks (Quercus spp.) and loblolly pine. This area of large mixed timber at both watersheds was the result of timber harvests in compliance with Texas BMPs, leaving the riparian forest as a contiguous buffer known as a streamside management zone (SMZ). The understory of both watersheds consists mostly of species such as dogwood (Cornus florida), sweetgum (Liquidambar 
styraciflua), various magnolias (Magnolia spp.), various hickories (Carya spp.), yaupon (Ilex vomitoria), sassafras (Sassafras albidum), and American beautyberry (Calicarpa americana).

Figure 2. F1 (a) and F2 (b) natural gas well pad layout at the Alto Experimental Watersheds, Texas, USA.

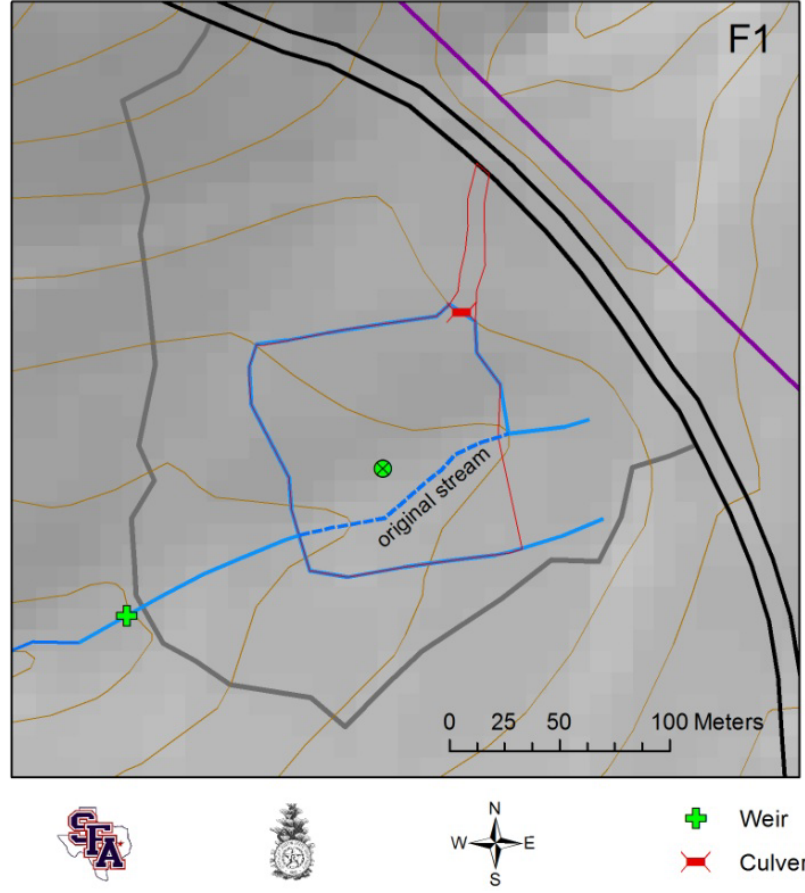

(a)

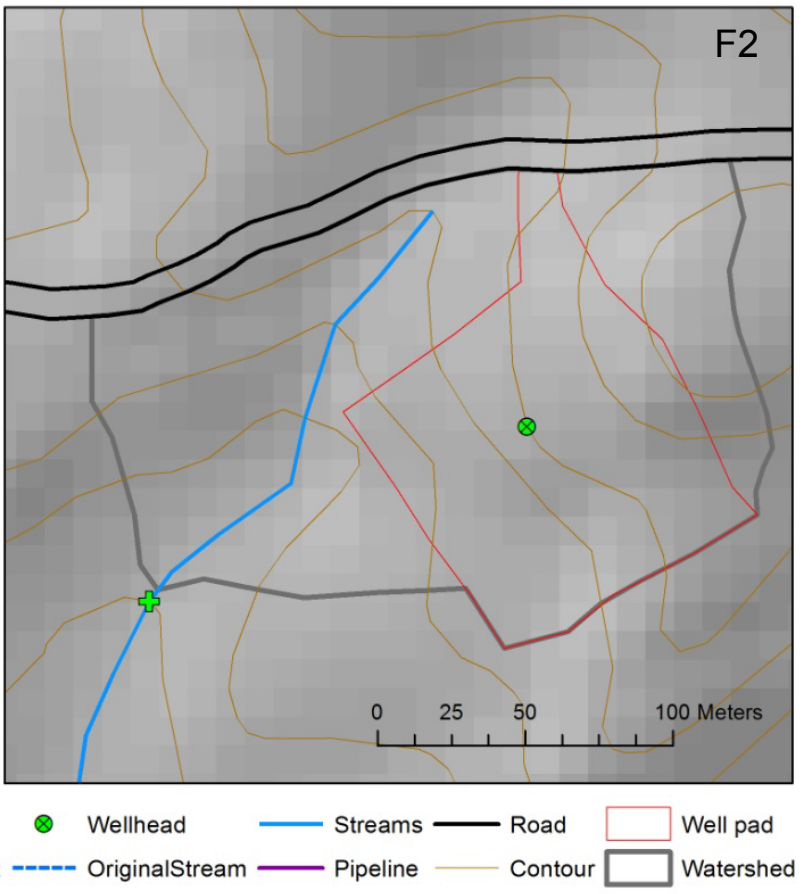

(b)

\subsection{Water Quantity and Quality}

In both streams, a v-notch weir was constructed approximately $80 \mathrm{~m}$ downstream from the pad (Figure 3).

In each weir, an AquaRod $^{\circledR}$ water level monitor was installed in the mouth of the flume. Unfortunately, stage data obtained from the AquaRods ${ }^{\circledR}$ were unreliable due the unexpectedly high sediment loads deposited in the weirs burying the capacitance rods. Streamflow was therefore estimated using the ArcAPEX model from precipitation measured at the sites [14]. ArcAPEX was calibrated and validated for these watersheds in earlier studies [15]. Rain gauges were located throughout the watershed and after each storm event precipitation data were collected.

As a result of the streamflow being ponded by the front plate of the weir, the coarse sediments were deposited in the drop box section on the floor of the weir. After each rain event this sediment was removed and weighed to determine the amount of sedimentation occurring in the stream channel (Figure 4). Dry mass was determined from a sub-sample of this sediment. The amount of sediment deposited in the drop box was later added to the amount of suspended sediment losses in stormflow. These losses were quantified using the flow estimated by ArcAPEX multiplied times the total suspended sediment (TSS) values that were obtained from stormwater samples. Sampling occurred from September 2008 to March 2010.

Water samples were collected from each weir using one of two techniques. The first technique utilized a Nalgene $^{\circledR}$ Storm Water Sampler (Figure 3). Within $24 \mathrm{~h}$ of each storm runoff event the 
sample bottle was removed and a clean, acid rinsed bottle was placed in the cylinder. These samplers were frequently buried by the large volumes of sediment. When this occurred, the second method was used, the grab sample method, in which a $1 \mathrm{~L}$ sample bottle was placed in the flow of the stream and a water sample was taken. Grab samples typically represented the recession phase of the hydrograph. Once the samples were collected from the field they were brought to the laboratory for analysis. The samples in the lab were analyzed using a $\operatorname{Hach}^{\circledR}$ DR/890 Datalogging Colorimeter and a Hach ${ }^{\circledR}$ sensION 156 Portable $\mathrm{pH} /$ Conductivity Meter according to approved United States Environmental Protection Agency (USEPA) methods [16]. Parameters analyzed included total suspended solids (TSS), total dissolved solids (TDS), $\mathrm{pH}$, conductivity (EC), total nitrogen (TN), ammonia $\left(\mathrm{NH}_{4}{ }^{+}\right.$), nitrate nitrogen $\left(\mathrm{NO}_{3}{ }^{-}\right)$, nitrite nitrogen $\left(\mathrm{NO}_{2}{ }^{-}\right)$, total phosphorus (TP), ortho-phosphate $\left(\mathrm{PO}_{4}{ }^{+}\right)$sulfate $\left(\mathrm{SO}_{4}{ }^{+}\right)$, iron (Fe), turbidity, color, salinity, calcium hardness and magnesium hardness. A paired T-test was employed to determine if mean water quality values were different by site at $=0.05$.

Figure 3. In-channel instrumentation for measuring total runoff (V-notch weir), stream level (Aquarod ${ }^{\circledR}$ ), water quality (Nalgene ${ }^{\circledR}$ Stormwater Sampler), and sediment (drop box) on the F2 sub-watershed before a storm event (a) and after a $6.3 \mathrm{~cm}$ rain event in April, 2009 at F1 (b); at the Alto Experimental Watersheds in Texas, USA.

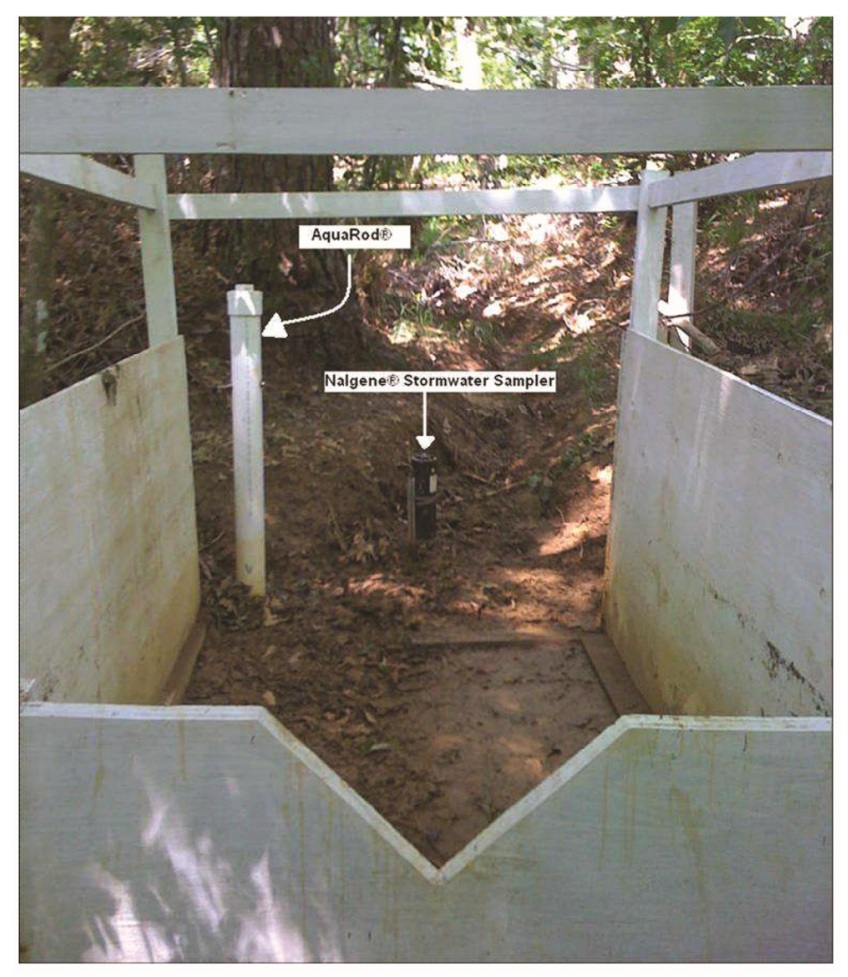

(a)

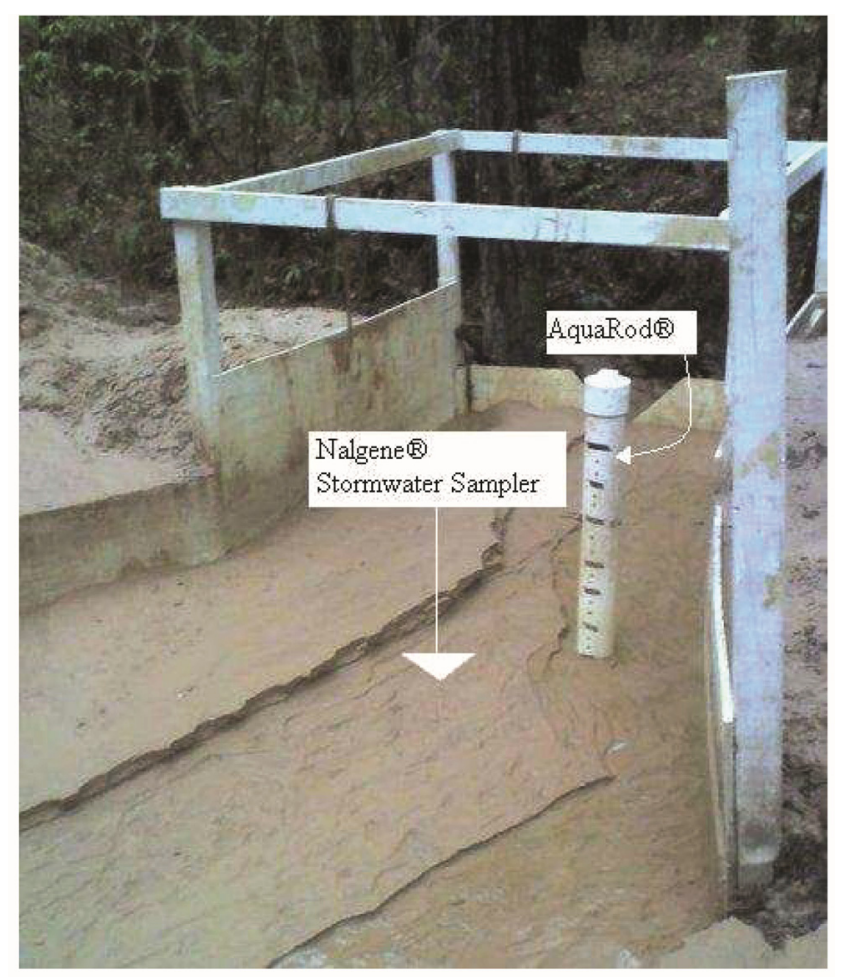

(b) 
Figure 4. Cumulative ArcApex simulated water yield and rainfall for two natural gas well locations, one placed directly in the stream channel (F1) and the other offset from the channel by a $15 \mathrm{~m}$ buffer (F2) at the Alto Experimental Watersheds, Texas, USA.

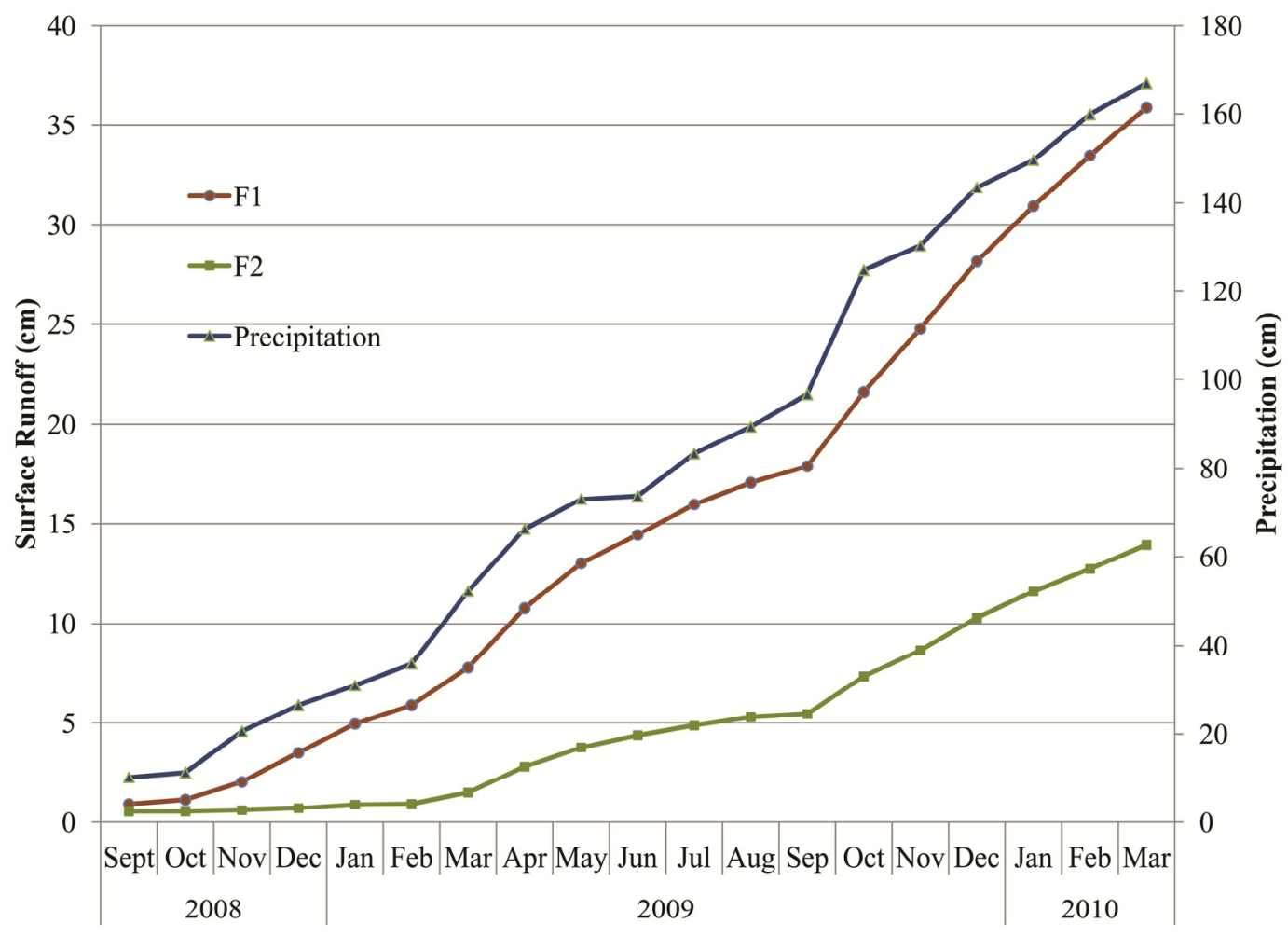

\section{Results}

In the small forested watersheds of East Texas, stream flow in headwater streams is typically intermittent and is mostly a product of storm runoff. The simulated water yield at F1 was significantly greater $(p<0.0001)$ than the water yield at F2 (Figure 4). In the first month of data collection (September 2008) the water yield at F1 was $0.915 \mathrm{~cm}$ and $0.545 \mathrm{~cm}$ at F2. Due to lower than average precipitation in the month of October, there was a decrease in storm runoff, but this decrease was most pronounced at F2, with $0.216 \mathrm{~cm}$ and $0.001 \mathrm{~cm}$ at $\mathrm{F} 1$ and $\mathrm{F} 2$ respectively. This trend continued throughout the study period, regardless of season. Percent runoff efficiency (runoff divided by precipitation) was different for two watersheds, $33.0 \%$ at $\mathrm{F} 1$ and $12.3 \%$ at F2.

Soil compaction of the well pad was much greater than in the rest of the watershed. The mean bulk density of the well pad at F1 was $2.04 \mathrm{~g} \mathrm{~cm}^{-3}$. Mean bulk density measurements taken in the surrounding watershed were $1.3,1.19$, and $0.99 \mathrm{~g} \mathrm{~cm}^{-3}$ for logging sets, skid trails, and undisturbed forest floor respectively.

Sediment yield was also significantly greater $(p<0.001)$ from F1 that F2 (Figure 5). Starting in September 2008, the sediment yield was $83 \mathrm{~kg} \mathrm{ha}^{-1}$ at F1 versus $10 \mathrm{~kg} \mathrm{ha}^{-1}$ at F2. Continuing through the winter of 2009, the total yield continued to increase at F1 over F2. The total sediment yield for the 2009 water year (September 2008-August 2009) was 19,561 kg versus $785 \mathrm{~kg}$ at the F1 and F2 watersheds, respectively. However, this does not take into account the differences in the percent of the watershed that was actually disturbed by the well site. The well site occupied about $24 \%$ of the total watershed area at F2 versus about $10 \%$ at F1. Therefore, it is also useful to compare the sediment 
yields per unit area disturbed by natural gas development in order to make meaningful comparisons with the clearcut watersheds. On this basis, the equivalent sediment losses for F1 and F2 were $13,972.1$ and $714 \mathrm{~kg} \mathrm{ha}^{-1} \mathrm{yr}^{-1}$ for the 2009 water year respectively, or 16,896 and 1,087 $\mathrm{kg} \mathrm{ha}^{-1} \mathrm{yr}^{-1}$ for F1 and F2, respectively, annualized for the entire 19 month (September 2008-March 2010) study period. About $56 \%$ of the sediment loss recorded at F1 was deposited in the flume, with less than $44 \%$ moving in the suspended form. However, at F2, 98\% of the sediment moved in the suspended form over the study period, with only $2 \%$ being deposited in the flume. Since sediment filled the flume on F1 for several runoff events, it is possible that these loss values underestimate the amount of coarse sediments actually eroded from the pad.

Figure 5. Cumulative sediment yield and rainfall for two natural gas well locations, one placed directly in the stream channel (F1) and the other offset from the channel by a $15 \mathrm{~m}$ buffer (F2) at the Alto Experimental Watersheds, Texas, USA.

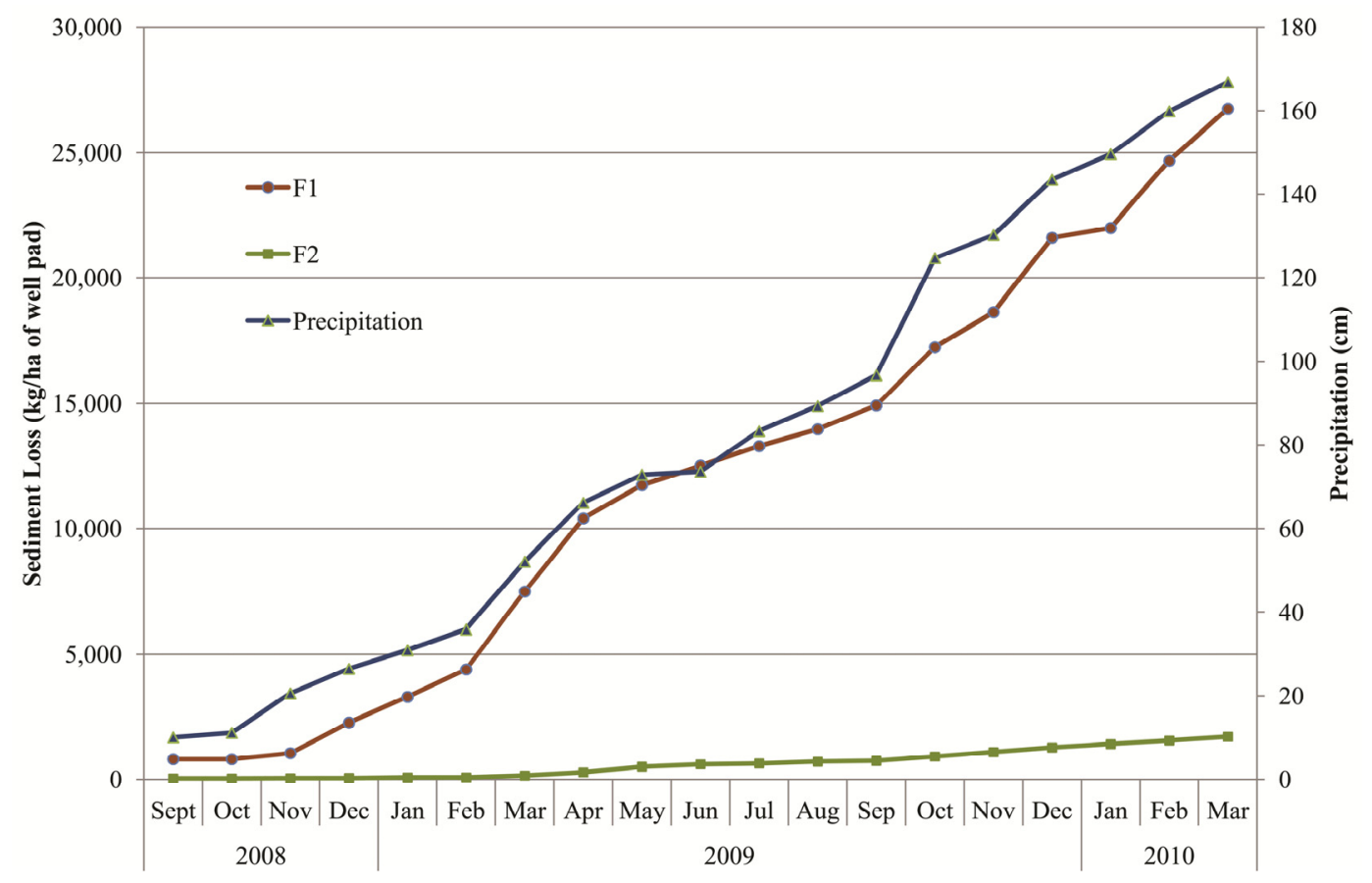

In terms of concentrations of other water quality parameters, differences between F1 and F2 were less pronounced (Table 1). For nutrients, only $\mathrm{PO}_{4}{ }^{+}$was significant, with the mean value being significantly greater at F2 than at F1. At F1, pH was also significantly greater, though these values were well below the Texas water quality standard minimum value of 6.0. Color was significantly greater at F1 than F2, probably associated with the higher amounts of sediment eroded from the pad at F1. However, there were no significant differences in either TSS or TDS. Salinity was significantly greater at F1 than F2, and this could have been attributed to an accidental spill of saline producer water that occurred in October 2008, but more sampling would have been required to establish this. The volume and chemical properties of this salt water was spilled was not tested. However, this spill did result in the death of several loblolly pine trees and understory vegetation down gradient of the well pad (Figure 6). 
When nutrient and metal concentrations were converted to mass losses per hectare, all of the losses were greater from $\mathrm{F} 1$ than $\mathrm{F} 2$, with $\mathrm{TDS}, \mathrm{TN}, \mathrm{NO}_{3}{ }^{-}, \mathrm{PO}_{4}{ }^{+}, \mathrm{SO}_{4}{ }^{+}$, and $\mathrm{Fe}$ being significantly greater ( $\alpha<0.05$ ) using the $T$-test (Table 2 ). Since streamflow was significantly greater at F1 throughout the study period (Figure 4), it would be expected that mass losses would also be greater.

Table 1. Mean concentrations for water quality parameters measured below two natural gas well sites (F1 and F2) from October 2008-March 2010 at the Alto Experimental watersheds in East Texas, USA.

\begin{tabular}{|c|c|c|c|}
\hline \multirow{2}{*}{ Water quality parameter } & \multicolumn{2}{|c|}{ Mean $^{1}$} & \multirow{2}{*}{$T$-test $p$-value } \\
\hline & F1 & F2 & \\
\hline Total Nitrogen $\left(\mathrm{TN}, \mathrm{mg} \mathrm{L}^{-1}\right)$ & 2.78 & 2.50 & 0.26 \\
\hline Ammonia $\left(\mathrm{NH}_{4}^{+}, \mathrm{mg} \mathrm{L}^{-1}\right)$ & 1.55 & 0.57 & 0.27 \\
\hline Nitrate $\left(\mathrm{NO}_{3}^{-}, \mathrm{mg} \mathrm{L}^{-1}\right)$ & 2.78 & 0.74 & 0.15 \\
\hline Nitrite $\left(\mathrm{NO}_{2}^{-}, \mathrm{mg} \mathrm{L}^{-1}\right)$ & 0.02 & 0.03 & 0.50 \\
\hline Total Phosphorus (TP, $\mathrm{mg} \mathrm{L}^{-1}$ ) & 0.57 & 0.72 & 0.59 \\
\hline Ortho-Phosphate $\left(\mathrm{PO}_{4}^{+}, \mathrm{mg} \mathrm{L}^{-1}\right)$ & 0.16 & $\underline{0.30}$ & 0.01 \\
\hline Total Suspended Solids (TSS, $\mathrm{mg} \mathrm{L}^{-1}$ ) & 335.72 & $2 \overline{88.33}$ & 0.40 \\
\hline Total Dissolved Solids (TSD, mg L ${ }^{-1}$ ) & 281.43 & 415.44 & 0.13 \\
\hline $\mathrm{pH}$ & $\underline{4.90}$ & 4.53 & 0.04 \\
\hline Conductivity $\left(\mu \mathrm{S} \mathrm{cm}^{-1}\right)$ & $4 \overline{61.06}$ & 554.65 & 0.30 \\
\hline Color $(\mathrm{CU})$ & $\underline{1231.28}$ & 576.58 & 0.04 \\
\hline Calcium Hardness $\left(\mathrm{mg} \mathrm{L}^{-1}\right)$ & 1.23 & 0.75 & 0.23 \\
\hline Magnesium Hardness $\left(\mathrm{mg} \mathrm{L}^{-1}\right)$ & 2.81 & 2.95 & 0.87 \\
\hline $\operatorname{Iron}\left(\mathrm{Fe}, \mathrm{mg} \mathrm{L}^{-1}\right)$ & 5.55 & 4.36 & 0.18 \\
\hline Salinity $\left(\mathrm{mg} \mathrm{L}^{-1}\right)$ & 0.24 & $\underline{0.41}$ & 0.02 \\
\hline Sulfate $\left(\mathrm{SO}_{4}^{+}, \mathrm{mg} \mathrm{L}^{-1}\right)$ & 6.43 & $\overline{5.30}$ & 0.23 \\
\hline
\end{tabular}

Note: ${ }^{1}$ Bold underlined values were significantly greater based on the paired $t$-test at $\alpha=0.05$.

Table 2. Total values for mass losses $\left(\mathrm{kg} \mathrm{ha}^{-1}\right)$ for water quality parameters measured below two natural gas well sites (F1 and F2) from October 2008-March 2010 at the Alto Experimental Watersheds in East Texas, USA.

\begin{tabular}{|c|c|c|c|}
\hline \multirow{2}{*}{ Water quality parameter } & \multicolumn{2}{|c|}{ Sum $^{1}$} & \multirow{2}{*}{$T$-test $p$-value } \\
\hline & F1 & F2 & \\
\hline Total Nitrogen (TN) & $\underline{10.84}$ & 3.08 & 0.00 \\
\hline Ammonia $\left(\mathrm{NH}_{4}^{+}\right)$ & $\overline{4.55}$ & 0.67 & 0.112 \\
\hline Nitrate $\left(\mathrm{NO}_{3}{ }^{-}\right)$ & $\underline{11.84}$ & 0.84 & 0.035 \\
\hline Nitrite $\left(\mathrm{NO}_{2}^{-}\right)$ & $\overline{0.10}$ & 0.05 & 0.217 \\
\hline Total Phosphorus (TP) & 2.53 & 1.42 & 0.059 \\
\hline Ortho-Phosphate $\left(\mathrm{PO}_{4}^{+}\right)$ & 0.72 & 0.47 & 0.042 \\
\hline Total Suspended Solids (TSS) & $\overline{\mathbf{1 , 1 9 6}}$ & 418 & 0.000 \\
\hline Total Dissolved Solids (TDS) & 969 & 559 & 0.032 \\
\hline Iron $(\mathrm{Fe})$ & $\overline{19.2}$ & 5.54 & 0.001 \\
\hline Sulfate $\left(\mathrm{SO}_{4}^{+}\right)$ & $\overline{21.53}$ & 6.43 & 0.000 \\
\hline
\end{tabular}

Note: ${ }^{1}$ Bold underlined total values were significantly greater based on the paired $t$-test at $\alpha=0.05$. 
Figure 6. Mortality of loblolly pine overstory trees (red/brown needles) and understory vegetation at F2 at the edge of the streamside buffer strip following an accidental spill in October 2008 of saline water produced during natural gas extraction at the Alto Experimental Watersheds in Texas, USA.

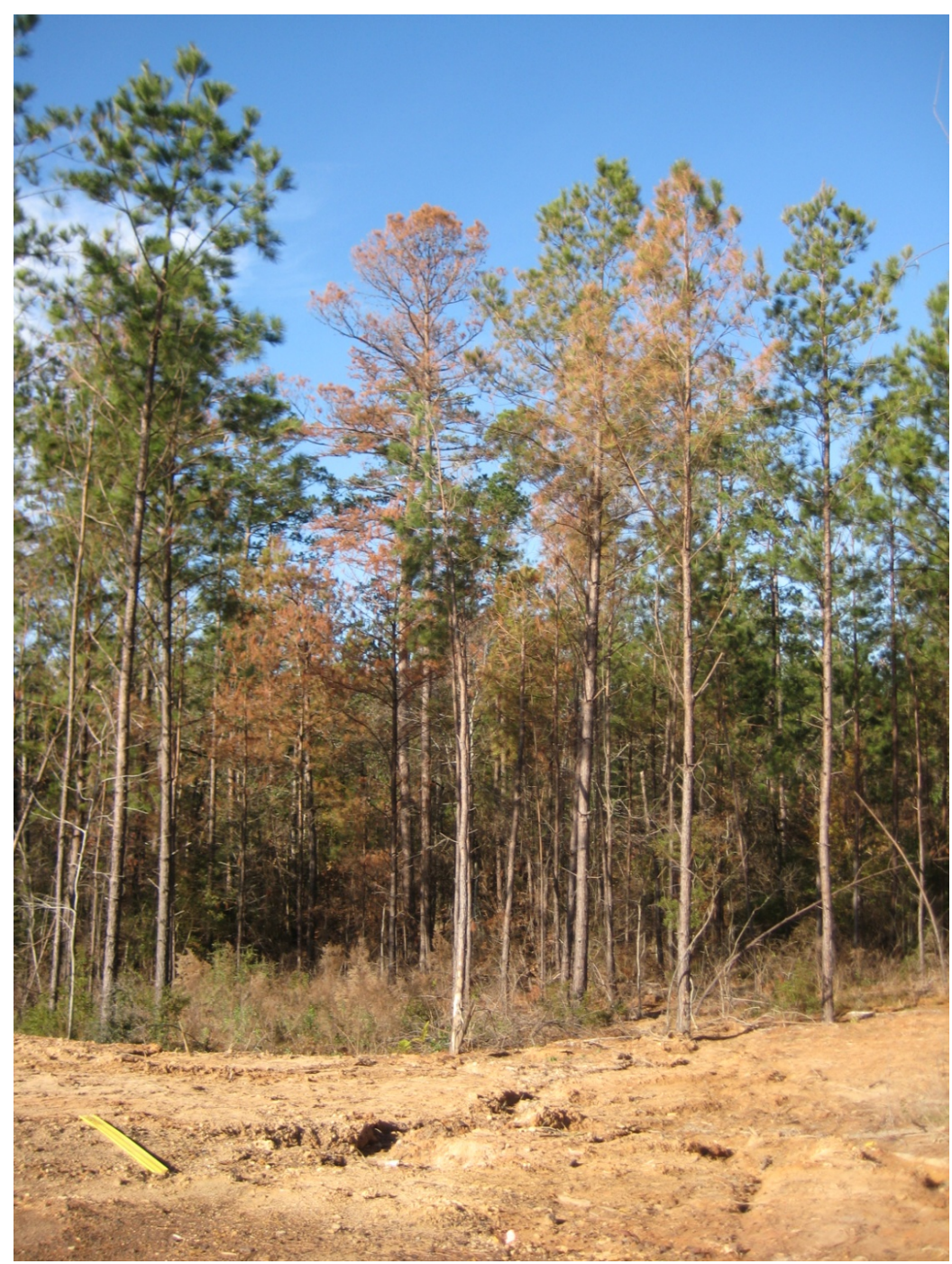

\section{Discussion}

\subsection{Storm Runoff}

Total runoff from these two natural gas well locations was much greater than would be expected from undisturbed areas in this region. In the undisturbed forested areas, direct surface runoff is uncommon. However, due to the significant increase in bare, compacted soils surface runoff was much more frequent. In addition, the significantly higher bulk density on the well locations resulted in less infiltration. McBroom et al. [17] found that for nearby undisturbed forests, annual runoff ranged between 0.64 and $10.32 \mathrm{~cm}$, depending on rainfall. Following clearcutting of the watersheds reported by McBroom et al. [17], annual runoff ranged between 7.82 and $9.79 \mathrm{~cm}$. This was comparable to runoff measured at F2 in the 2009 water year of $9.58 \mathrm{~cm}$. However, the clearcut reported by McBroom et al. [17] covered an average of $75 \%$ of the total watershed area, where the well location at 
F2 only occupied about $10 \%$ of the total watershed area. Even when the gas well pad was offset by $15 \mathrm{~m}$ from the stream, it still had a proportionally greater impact on runoff than forest management. For the well pad directly in the stream channel, the effects on runoff were much greater, with $24.67 \mathrm{~cm}$ of runoff in the 2009 water year. In addition, runoff efficiency following clearcutting on adjacent watersheds increased from $1 \%$ pre-harvest to $9 \%$ post harvest, compared with $33 \%$ and $12 \%$ on F1 and F2, respectively.

\subsection{Sediment Losses}

In terms of total sediment yield, results from this study are much greater than reported from proximate watershed studies, indicating the greater relative impact of natural gas development. For undisturbed forestlands, sediment yield averaged about $42 \mathrm{~kg} \mathrm{ha}^{-1}$ [17]. Following clearcut harvesting and site preparation in 2003, losses increased from 111 to $224 \mathrm{~kg} \mathrm{ha}^{-1} \mathrm{yr}^{-1}$, though these differences were not found to be statistically significant [17]. In that study, a streamside management zone (SMZ) with a minimum total width of $30 \mathrm{~m}$ was retained around all stream channels. In 1981 these same watersheds were clearcut harvested and no SMZ was retained, and the following site preparation, sediment losses averaged $2917 \mathrm{~kg} \mathrm{ha}^{-1}$ first year after harvest [18]. Losses returned to levels measured in undisturbed forests by the second year after harvest in both 1981 [18] and in 2003 [15]. While large sediment plumes were observed to have eroded from both gas well locations, at F2 lobes of coarser sediments were trapped by the riparian vegetation and surface cover before reaching the stream channel. On F1, the $13,972 \mathrm{~kg} \mathrm{ha}^{-1}$ of disturbance for 2009 largely resulted from sediment moving from the fill slope on the back side of the pad directly into the stream channel (Figure 7).

Construction of a natural gas well location in Denton, Texas resulted in 54,000 kg ha $\mathrm{yr}^{-1}$ of erosion [7]. This represents sediment that eroded from the pad, but may not have necessarily entered the stream channel. Using the RUSLE 2.0 model, Waschal et al. [10] concluded that good sediment control practices and BMPs can reduce sediment yields from natural gas well pads by 52\%-93\%. Similarly in the current study, the 94\% difference in sediment between F1 and F2 can be attributed in part to the $15 \mathrm{~m}$ riparian buffer on $\mathrm{F} 2$ and better stormwater management.

One area of continued concern on F1 is that no efforts at site stabilization or revegetation were attempted following the initial failed attempt at seeding with rye grass. Significant rill and small gully erosion resulted from storm runoff flowing off the compacted pad area and down onto the sloping fill material where the reserve pit had been. Unlike results reported by Williams et al [7], after four years, the F1 well pad continued to erode with little evidence of natural stabilization, and natural vegetation remained sparse due to the poor condition of this fill material as a plant growing medium.

Similar to what was found with natural gas wells in the Fernow Experimental Forest in West Virginia, silt fences were inadequate at stopping these large sediment volumes [19]. Silt fences were installed down-gradient of the well location during construction, but they were installed about $0.25 \mathrm{~m}$ above the old stream channel on F1 and were overwhelmed by the large sediment loads, making silt fence ineffective at controlling these large volumes of sediment (Figure 8). Like with the wells constructed in the Fernow [19], improper installation resulted in the ineffectiveness of silt fence as a stormwater BMP. Silt fences functioned as intended on F2 due to proper installation and a lower overall sediment load that did not overwhelm their design capacity. 
Figure 7. Sediment plume below the F2 natural gas well location trapped by riparian forest vegetation before entering the stream channel at the Alto Experimental Watersheds in Texas, USA.

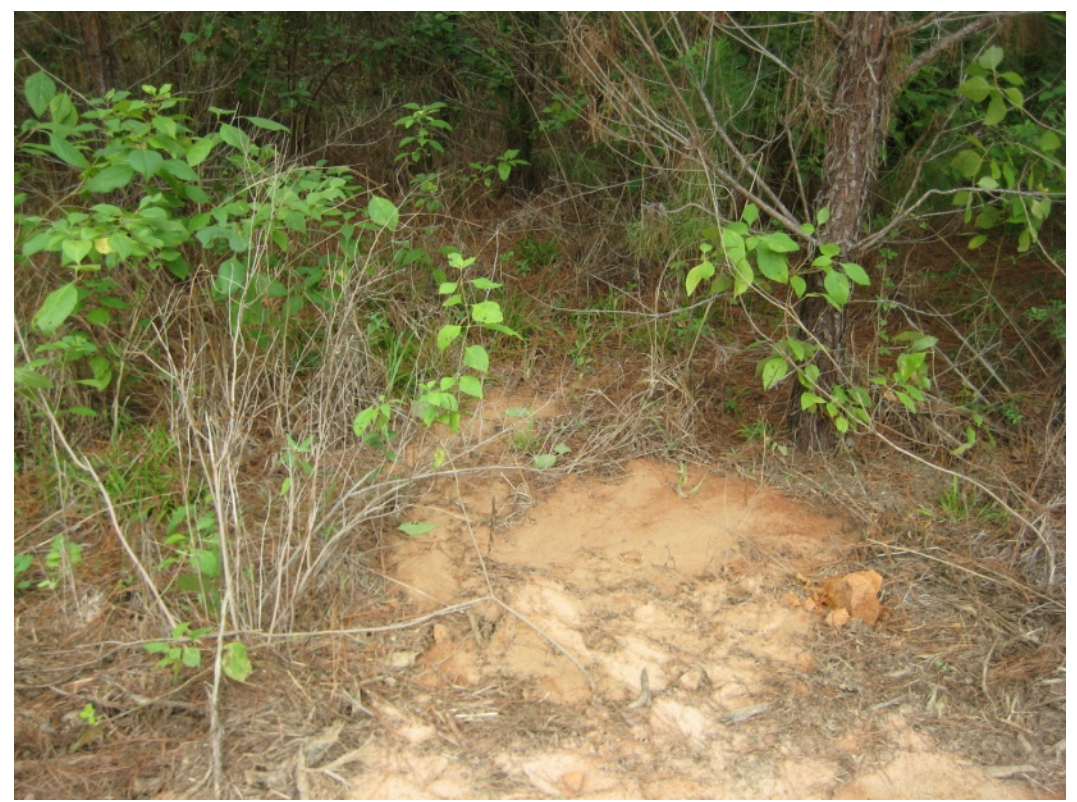

Figure 8. Silt fence installed below the natural gas well pad at F1 illustrating the ineffectiveness of this sediment control technique due to poor installation and large sediment volumes eroded at the Alto Experimental Watersheds in Texas, USA.

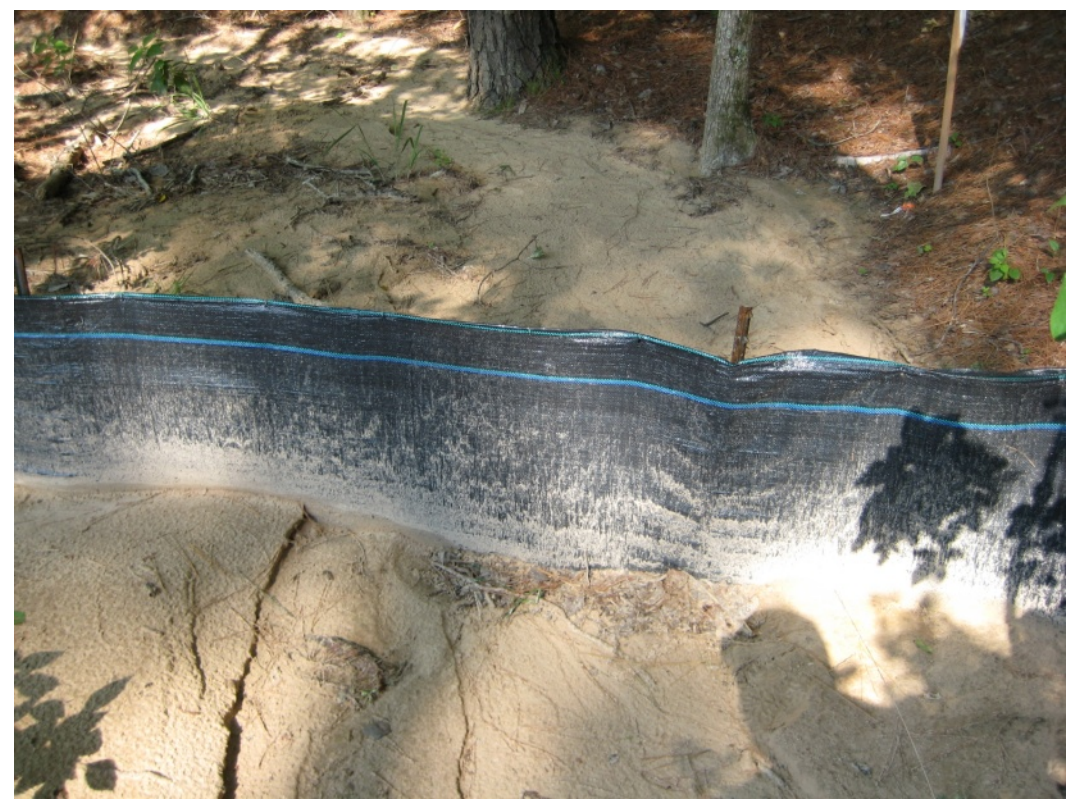

Beyond the continued erosion of the well pad, another significant concern that exists is that this deposited sediment will have long term consequences for the aquatic ecosystem. The original stream channel below the well on F1 was buried by about $0.5 \mathrm{~m}$ of sediment and the original pool, riffle, and glide aquatic habitats were obliterated. Sediment loading of this magnitude can have dramatic effects on lotic food webs [20]. For streams in the southeastern United States, hundreds of years if not millennia may be required to naturally purge large volumes of sediments out of regional stream and 
river networks [21]. This represents a localized legacy sediment issue comparable to what occurred in this region due to poor agricultural practices in the 19th Century. Effective and systematic implementation of soil conservation practices is needed to ensure that significant land use alterations do not impair surface waters in regions with extensive natural gas development.

\subsection{Water Quality}

The effects of natural gas development on water quality parameters were less significant than with sedimentation. Concentrations of most parameters were not significantly different between F2 an F1. However, overall runoff volumes were greater at F1 than F2, so when concentrations were converted to mass losses, the most of the water quality parameters were significantly greater at F1 than F2. The larger runoff volumes from F1 may have diluted the concentrations, but the overall mass export was significantly greater. This indicates that reducing the export of nutrients and metals from natural gas well pads is dependent on effective stormwater management. At F1, there was no buffering between the well pad and the stream, meaning that direct contributions of contaminants occurred without the benefits of filtration provided by riparian buffer strips.

As noted in the Results section, a producer water spill at F2 did result in the death of several trees along the stream channel, and this may account for the significantly higher salinity values at F2 (Figure 6). Differences in water quality were not observed with other parameters. Ground water was pumped into the stream channel immediately after the spill for several days in order to dilute the effects of the spill. While the water quality of the spilled water was not characterized, this remediation measure may have been adequate to reduce the impacts on water quality parameters that could be directly measured. However, the death of the riparian trees immediately in the flow area of the spill indicates that the direct ecological effects may require different remediation strategies.

\section{Summary and Conclusions}

Natural gas development is important for maintain economic prosperity and for providing a necessary energy source until renewable energy sources become more viable [22]. However, significant impacts on surface water resources were measured in this study when a gas well pad was constructed with little attention given to surface drainage patterns. Unfortunately, this was not an isolated incident on this lease area, with a pad being constructed in a perennial stream a few km north from F1 and another pad platted and surveyed over another intermittent stream nearby. Erosion rates that result from this practice are orders of magnitude greater than other land uses in this region. The $13,972 \mathrm{~kg} \mathrm{ha}^{-1} \mathrm{yr}^{-1}$ per unit disturbance area recorded at F1 for the 2009 water year compared with the $714 \mathrm{~kg} \mathrm{ha}^{-1} \mathrm{yr}^{-1}$ recorded at F2 indicates that natural gas wells can be constructed without significant water quality degradation when necessary erosion control measures are implemented. However, once stream channels are filled in and obliterated, remediative BMPs like silt fence and revegetation are unlikely to have a significant effect in reducing erosion and minimizing aquatic habitat degradation. The stormwater generated by even relatively small rain events washed pollutants directly off the pad into the stream, with no opportunity for deposition and filtration.

Since construction of gas well pads in the state of Texas is not currently regulated like other construction sites, the responsibility for ending the practice of stream channel obliteration for gas well 
pad construction falls on the industry to self-regulate this practice. There is a precedent for effective industrial self-regulation in Texas, where forest practices like clearcutting along intermittent and perennial streams are not regulated by state or federal environmental agencies. After research demonstrated that clearcutting could have significant impacts on water resources [23], voluntary BMPs that restrict forest harvesting along streams were adopted by the forest industry in Texas by the mid-1980s. After an extensive education and outreach campaign, 98\% of forestry activities in Texas voluntarily retained streamside buffers by 2011 [8]. Like the production of wood and fiber, development of natural gas resources is necessary for society. However, this must be conducted with effective and systematic implementation of soil and water conservation practices that ensure these land use changes will not impair surface waters in regions where extensive natural gas development will occur.

\section{Acknowledgments}

Funding was provided by the National Council for Air and Stream Improvement (NCASI) and the Waters of East Texas (WET) Center at the Arthur Temple College of Forestry and Agriculture at Stephen F. Austin State University. The Campbell Group provided land access for this study and valuable support.

\section{References}

1. EIA (Energy Information Administration). Annual Energy Outlook with Projections to 2035; DOE/EIA-0383(2012); U.S. Energy Information Administration: Washington, DC, USA, 2012.

2. Grant, J.; Parker, L.; Bar-Ilan, A.; Kemball-Cook, S.; Yarwood, G. Development of Emissions Inventories for Natural Gas Exploration and Production Activity in the Haynesville Shale; East Texas Council of Governments: Kilgore, TX, USA, 2009.Available online: http://www.netac.org/ UserFiles/File/NETAC/9_29_09/Enclosure_2b.pdf (accessed on 12 November 2012).

3. Louisiana Department of Natural Resources (LDNR). Louisiana Hydraulic Fracturing State Review; Louisiana Department of Natural Resources: Baton Rouge, LA, USA, 2011.

4. Nicot, J.P.; Scanlon, B.R. Water use for shale-gas production in Texas, USA. Environ. Sci. Technol. 2012, 46, 3580-3586.

5. Entrekin, S.; Evans-White, M.; Johnson, B.; Hagenbuch, E. Rapid expansion of natural gas development poses a threat to surface waters. Front. Ecol. Environ. 2011, 9, 503-511.

6. United States Environmental Protection Agency (USEPA). National Water Quality Inventory: Report to Congress; EPA 841-R-08-001; United States Environmental Protection Agency Office of Water: Washingdon, DC, USA, 2009; p. 43.

7. Williams, H.F.L.; Havens, D.; Banks, K.; Wachal, D. Field-based monitoring of sediment runoff from natural gas well sites in Denton County, Texas, USA. Environ. Geol. 2008, 55, 1463-1471.

8. Simpson, H.; Coup, C.; Duncan, C. Voluntary Implementation of Forestry Best Management Practices in East Texas; Texas Forest Service: Lufkin, TX, USA, 2011; p. 54.

9. McBroom, M.W.; Beasley, R.S.; Chang, M.; Ice, G.G. Water quality effects of clearcut harvesting and forest fertilization with best management practices. J. Environ. Qual. 2008, 37, 114-124. 
10. Wachal, D.J.; Banks, K.E.; Hudak, P.F.; Harmel, R.D. Modeling erosion and sediment control practices with rusle 2.0: A management approach for natural gas well sites in Denton County, TX, USA. Environ. Geol. 2009, 56, 1615-1627.

11. Chang, M.; Clendenon, L.D.; Reeves, H.C. Characteristics of a Humid Climate, Nacogdoches, Texas; College of Foestry, Stephen F. Austin State University: Nacogdoches, TX, USA, 1996; p. 211.

12. University of Texas at Austin Bureau of Economic Geology. Geologic Atlas of Texas, Palestine Sheet; University of Texas at Austin Bureau of Economic Geology: Austin, TX, USA, 1968.

13. Mowery, I.C. Soil Survey Cherokee County Texas; United States Department of Agriculture Soil Conservation Service: Washington, DC, USA, 1959; p. 68.

14. Tuppad, P.; Winchell, M.; Wang, X.; Srinivasan, R.; Williams, J. ArcAPEX: ArcGIS interface for agricultural policy environmental extender (APEX) hydrology/water quality model. Int. Agric. Eng. J. 2009, 18, 59-71.

15. Wang, X.; Saleh, A.; McBroom, M.W.; Williams, J.R.; Yin, L. Test of APEX for nine forested watersheds in East Texas. J. Environ. Qual. 2007, 36, 983-995.

16. Hach Company. Dr/890 Colorimeter Procedures Manual, 9th ed.; Hach Company: Loveland, CO, USA, 2009; Volume 48470-22; p. 614.

17. McBroom, M.W.; Beasley, R.S.; Chang, M.; Ice, G.G. Storm runoff and sediment losses from forest clearcutting and stand reestablishment with best management practices in the southeastern United States. Hydrol. Process. 2008, 22, 1509-1522.

18. Blackburn, W.; Wood, J.; DeHaven, M. Storm flow and sediment losses from site-prepared forestland in east Texas. Water Resour. Res. 1986, 22, 776-784.

19. Adams, M.B. Effects of Development of a Natural Gas Well and Associated Pipeline on the Natural and Scientific Resources of the Fernow Experimental Forest; U.S. Department of Agriculture, Forest Service, Northern Research Station: Newtown Square, PA, USA, 2011.

20. Henley, W.; Patterson, M.; Neves, R.; Lemly, A.D. Effects of sedimentation and turbidity on lotic food webs: A concise review for natural resource managers. Rev. Fish. Sci. 2000, 8, 125-139.

21. Jackson, C.; Martin, J.; Leigh, D.; West, L. A southeastern piedmont watershed sediment budget: Evidence for a multi-millennial agricultural legacy. J. Soil Water Conserv. 2005, 60, 298-310.

22. Kerr, R.A. Natural gas from shale bursts onto the scene. Science 2010, 328, 1624-1626.

23. Ice, G.G. History of innovative best management practice development and its role in addressing water quality limited waterbodies. J. Environ. Eng. 2004, 130, 684-689.

(C) 2012 by the authors; licensee MDPI, Basel, Switzerland. This article is an open access article distributed under the terms and conditions of the Creative Commons Attribution license (http://creativecommons.org/licenses/by/3.0/). 